\title{
Abundance of gelatinous carnivores in the nekton community of the Antarctic Polar Frontal Zone in summer 1994
}

\author{
F. Pagès ${ }^{1, *}$, M. G. White ${ }^{2}$, P. G. Rodhouse ${ }^{2}$ \\ 'Alfred-Wegener-Institut für Polar- und Meeresforschung, Columbusstraße, D-27568 Bremerhaven, Germany \\ ${ }^{2}$ British Antarctic Survey, NERC, High Cross, Madingley Road, Cambridge CB3 0ET, United Kingdom
}

\begin{abstract}
The species composition, abundance, vertical distribution, biovolume and carbon content of gelatinous nekton in the Antarctic Polar Frontal Zone are described from a series of RMT25 hauls collected from a series of $200 \mathrm{~m}$ depth layers between 0 and $1000 \mathrm{~m}$. In total, 13 species of medusa, 6 species of siphonophore, 3 species of ctenophore and 1 species of salp and nemertean were identified. On average gelatinous organisms contributed $69.3 \%$ to the biovolume and $30.3 \%$ to the carbon content of the samples, although the ranges were high $(0$ to $98.9 \%$ and 0 to $62.6 \%$ respectively). The most important contributor to the biovolume and carbon content was the scyphomedusan Periphylla periphylla. Some specific assoclations and restricted vertical distributions were related to trophic interactions among ostracods, amphipods and cnidarians. Observations made near South Georgia showed that medusae and ctenophores were preyed upon by albatrosses and notothenioid fish respectively. The results support the premise that gelatinous organisms are a major and, at times, are the main component of the oceanic macroplankton/nekton community in the Southern Ocean.
\end{abstract}

KEY WORDS: Gelatinous nekton Southern Ocean Wet biomass Carbon content Assemblages

\section{INTRODUCTION}

The nekton communities in the Southern Ocean comprise 4 main groups of organisms: crustaceans, mesopelagic fish, squid and gelatinous forms. Their relative importance in the pelagic ecosystem is usually reported in terms of biomass (i.e. Everson \& Miller 1994, Kock \& Shimadzu 1994). Antarctic krill Euphausia superba Dana is generally considered to be the key organism in the marine Antarctic ecosystem. More critical studies have shown that krill abundances can vary considerably; low biomass and total absence are sometimes reported from areas of the Southern Ocean where it is normally abundant (Heywood et al. 1985) During these conditions other organisms, for example

\footnotetext{
- Correspondence address: Institut de Ciències del Mar (CSIC), Plaça del Mar s/n, E-08039 Barcelona, Spain

E-mail: fpages@1cm.csic.es
}

suspension feeding pelagic tunicates (salps), become dominant (Huntley et al. 1989)

Recently, the distribution and biology of gelatinous organisms have received more attention in the Antarctic (Pagès et al. 1994, Piatkowski et al. 1994, Rodhouse et al. 1994, Siegel \& Loeb 1995) as it has become evident that this previously neglected group plays a substantial role in the Southern Ocean ecosystem. It is difficult to assess the role of gelatinous organisms using conventional sampling methods, but observations from manned submersibles have elucidated behaviours and associations that are impossible to ascertain from net collected material (e.g. Janssen et al. 1989). Data on the distribution and biomass of the gelatinous macroplankton and nekton from the Southern Ocean is based mainly on information about salps, indicating that these are strong filter-feeders and may compete with krill for food resources (Reinke 1987, Huntley et al. 1989). Quantitative data, based on number of specimens (for medusae and ctenophores), number of poly- 
gastric stages and eudoxids (for calycophoran siphonophores), number of colonies (for physonect siphonophores) and sexual stages (for salps and doliolids), are extremely sparse. In addition, the systematic data can be in doubt when the identifications have been made by those unfamiliar with the taxa.

Nonetheless, from quantitative studies made in the Southern Ocean, it is known that gelatinous organisms show high species diversity, and relatively high abundances and biovolumes (Pagès \& Kurbjeweit 1994, Pagès et al. 1994, Pugh et al. in press). These studies are rare and more investigations are necessary to demonstrate to biologists and modellers that gelatinous organisms have to be taken into account when investigating the whole pelagic ecosystem

The main objective during the second leg of the RRS 'James Clark Ross' Cruise JR06 (February-March 1994) was to carry out a closely integrated physical and biological programme in order to investigate the predator-prey interactions in an area shown to be frequented by squid predators. Squid represent the highest trophic level in the epipelagic zone at the Antarctic Polar Frontal Zone (APFZ) (Rodhouse \& White 1995, Rodhouse et al. 1996) but the biological collections consisted predominantly of mesopelagic fishes and gelatinous organisms (British Antarctic Survey 1995).

This paper describes the species composition, vertical distribution and abundance of the gelatinous macroplankton and nekton in the vicinity of the Polar Frontal Zone in the South Georgia sector of the Southern Ocean (Fig. 1). Likewise its wet biovolume and carbon content were estimated and compared with those of non-gelatinous nekton.
(Netherlands) 2800 pelagic trawl (head rope $93.2 \mathrm{~m}$ ); a $2 \mathrm{~m}^{2}$ horizontal - Antarctic multiple plankton sampler (H-AMPS); and a $1 \mathrm{~m}^{2}$ rectangular frame neuston net (F-net)

The wet biovolume of plankton and nekton was measured by displacement soon after the samples came onboard. The larger zooplankters were sorted into major groups to characterise the size spectra, and the gelatinous components segregated for more detailed treatment. All gelatinous forms were pooled to estimate biovolume and the percentage contribution to the whole sample.

The medusae and siphonophores, both asexual and sexual stages, from the RMT25 samples were identified to species level. Specific protocols were adopted in order to estimate the actual number of specimens of siphonophore present. Specimens of Rosacea sp. comprise an opposed pair of identical nectophores, so the number of nectophores found was rounded up to an even number and divided by 2 . The numbers of bracts and gonophores of this species were not included in the analyses as they remain attached to the stem. In the case of Vogtia serrata (Moser) the number of nectophores present on each animal is approximately 8 to 15. Since these are of variable size, and the smallest are likely to be lost through the meshes of the net, we have assumed a standard value of 10 per animal.

The British Antarctic Survey down-wire net monitor (DWNM) was used to control the sampling equipment and monitor water conditions while the RMT25 and $\mathrm{H}$ AMPS nets were deployed. The volume of water filtered by each net was calculated by averaging the flow rate data over $2 \mathrm{~s}$ intervals and these values were aver-

\section{MATERIAL AND METHODS}

The samples were collected using an opening-closing rectangular midwater trawl with a $25 \mathrm{~m}^{2}$ aperture (RMT25) (cf Piatkowski et al. 1994). The nekton community was sampled from the surface to $1000 \mathrm{~m}$ in $200 \mathrm{~m}$ depth strata during daylight and after dark. In addition, target fishing was undertaken in biomass rich layers (50-100, 300-350, $375-400 \mathrm{~m}$ ) and at 50 and $600 \mathrm{~m}$. To sample a layer, the net was towed obliquely down through the water column by slowly paying out the warp, while maintaining the net speed at $\sim 3 \mathrm{kt}\left(1.5 \mathrm{~m} \mathrm{~s}^{-1}\right)$.

The RMT25 was the main net used to collect quantitative data but additional samples were collected using other gear in order to sample specific depth strata and different size spectra. These were: a Ymuiden Stores

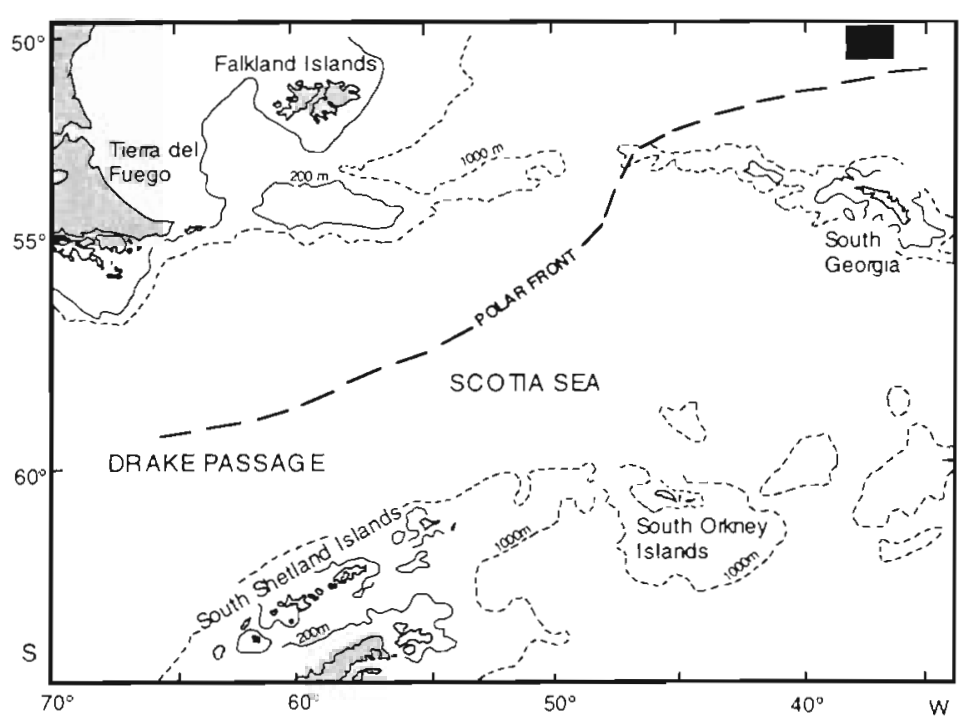

Fig. 1 Western part of the Atlantic sector, Southern Ocean. (ם) Sampling area, north of South Georgia 
aged to give the mean flow for the duration of a tow. The duration was derived from the 'net-state' signal from the DWNM. Volume of water filtered by each net was then calculated using the average flow data and duration data, assuming a $25 \mathrm{~m}^{2}$ mouth area (C. Swanson pers. comm.). Filtered volumes for the pelagic trawl and F-net were estimated from swept area calculations.

\section{RESULTS AND DISCUSSION}

\section{Hydrography}

The sampling area was located in the Antarctic Circumpolar Current between the Polar Front and the Subantarctic Front. Potential temperature decreased from $6.0^{\circ} \mathrm{C}$ at the surface to $3.0^{\circ} \mathrm{C}$ at $250 \mathrm{~m}$ depth (Fig. 2). Salinity was low (34.0 psu) at the surface (Stn 334) and increased smoothly to 34.4 psu at $500 \mathrm{~m}$ indicating the presence of Antarctic Intermediate Water. Potential temperature was very stable between 300 and $1000 \mathrm{~m}$ depth $\left(2.5\right.$ and $2.3^{\circ} \mathrm{C}$ respectively).

\section{Distribution and abundance}

The gelatinous organisms collected consisted of hydroidomedusae (13 spp.), siphonophores (6 spp.), scyphomedusae (3 spp.), ctenophores (3 spp.), salps (1 sp.) and nemerteans (1 sp.) (Table 1). Scyphomedusans were the most conspicuous component of the RMT25 samples because of their large size and high wet biovolume. Although their density was low, they were present in almost all hauls and at all depths.
Fig. 3 shows the occurrence and depth distribution of gelatinous zooplankton collected at the sampling area. The scyphomedusan Periphylla periphylla (Péron \& Lesueur) (up to $35 \mathrm{~cm}$ in diameter), the anthomedusan Calycopsis borchgrevinki (Browne) (maximum diameter $27 \mathrm{~mm}$ ) and the siphonophore Rosacea sp. (definitive nectophore up to $19 \mathrm{~mm}$ in length) were the only species collected in all depth ranges between $1000 \mathrm{~m}$ and the surface. $P$. periphylla appeared to show a diel vertical migration, with most of the specimens occurring between 400 and $1000 \mathrm{~m}$ during the day, but large ones were collected in the surface $200 \mathrm{~m}$ at night.

Other gelatinous organisms were mainly collected below $200 \mathrm{~m}$ (Fig. 3). Atolla wyvillei Haeckel (up to $72 \mathrm{~mm}$ in diameter) and $A$. chuni Vanhöfen (maximum diameter $61 \mathrm{~mm}$ ) were always collected between 600 and $1000 \mathrm{~m}$ during the day, but they also occurred in the 400-600 $\mathrm{m}$ depth range during the night, which suggests these species also exhibit a diel upward migration. The trachymedusae Halicreas minimum Fewkes (25 $\mathrm{mm}$ in diameter) and Crossota brunnea Vanhöffen (maximum width $43 \mathrm{~mm}$ ) showed the same vertical distribution, and both increased in abundance from $400 \mathrm{~m}$, their upper depth limit, to $1000 \mathrm{~m}$. Rosacea $\mathrm{sp}$. was the only common siphonophore and most specimens were collected between 200 and $600 \mathrm{~m}$. The remaining cnidarians occurred in very low densities (Table 1), mostly between 400 and $1000 \mathrm{~m}$. The number of cnidarian species tended to increase with depth and reached the highest species diversity (19 spp.) in the 600-800 m depth range (Fig. 3).

Some specimens of Salpa thompsoni Foxton were collected but in much lower numbers than are usually found in this area. For instance, they were extremely abundant during the previous year (A. W A. Murray
Fig. 2. Potential temperature $\left({ }^{\circ} \mathrm{C}\right)$ structure of the water column $(0-1000 \mathrm{~m})$ along the CTD transect, 12-13 February 1994 The water column is shaded where the RMT25 and pelagic trawl were used

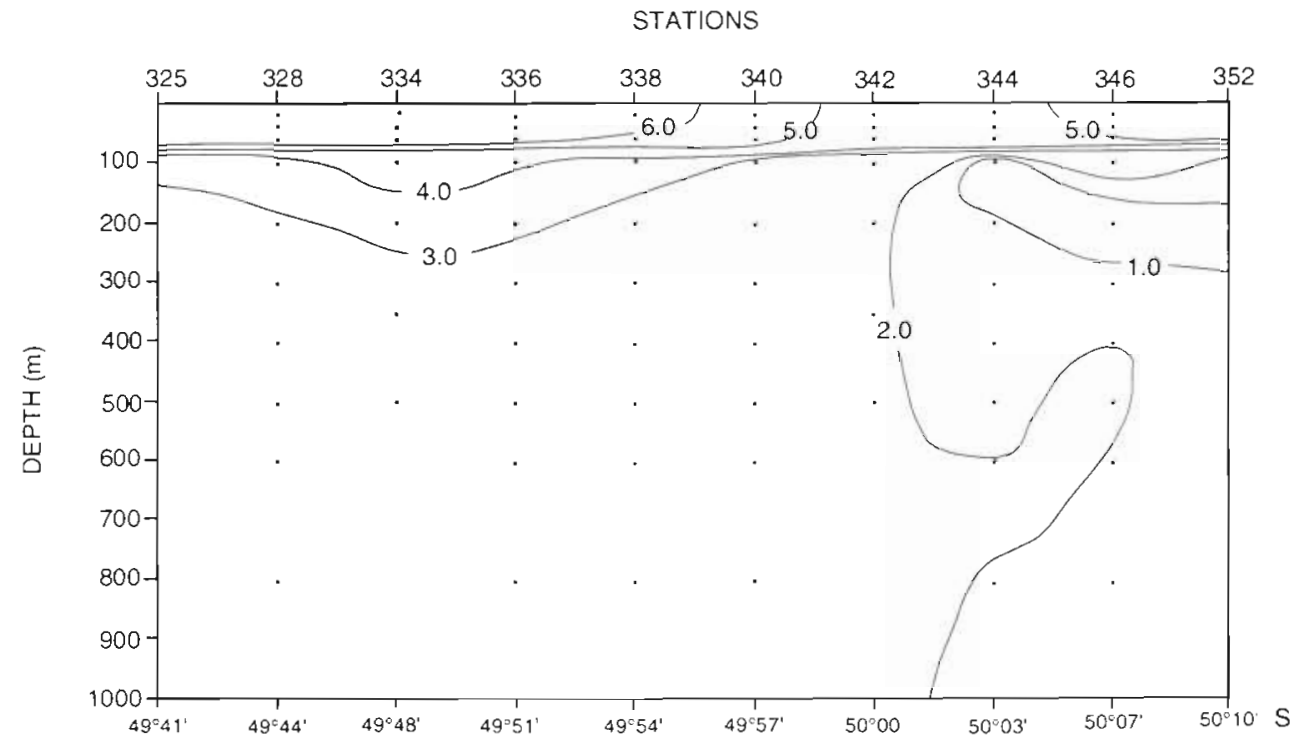




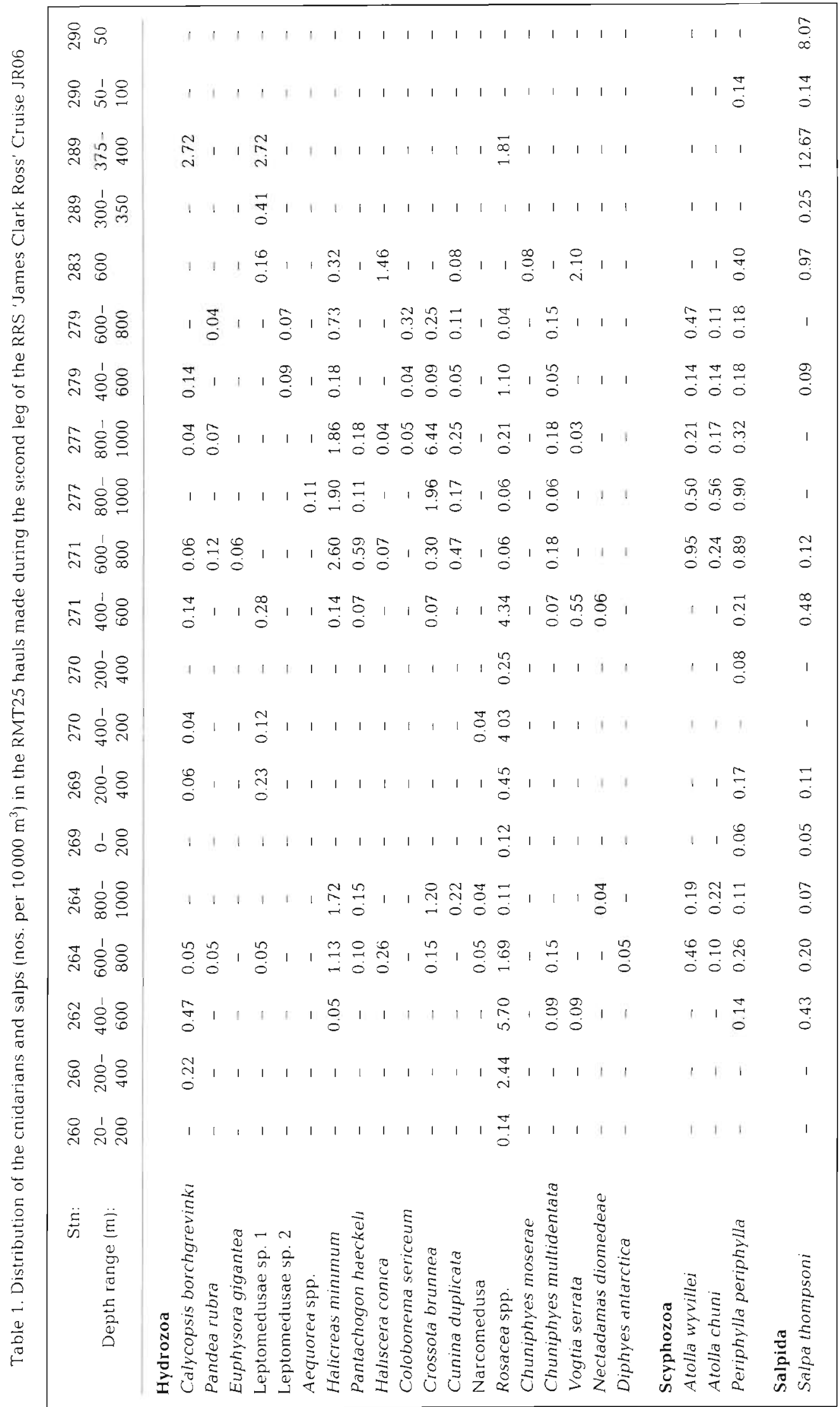


pers comm.). A few specimens of the deep-water nemertean Pelagonemertes rollestoni Moseley were captured in the $600-800 \mathrm{~m}$ depth range.

Abundances near the APFZ were lower when compared with the gelatinous macro- and megaplankton collected by an RMT 1 $8 \mathrm{M}$ (mesh size $4.5 \mathrm{~mm}$ ) in the Weddell Sea (Pagès et al. 1994). However, we believe that biomass estimates will be underestimates because only the gelatinous organisms larger than $20 \mathrm{~mm}$ in diameter would be collected quantitatively by the RMT25, as smaller or damaged specimens would pass through the $19 \mathrm{~mm}$ meshes in the anterior third of the net. Another factor that may influence the net efficiency is bioluminescence. Many gelatinous zooplankton are bioluminescent (Galt 1989) and Atolla, Periphylla and Aequorea are known to be bioluminescent medusae (Shimomura et al. 1962, Herring 1990). We presume that these will emit bioluminescent responses when disturbed or caught by the net since defense is the cause of most mechanically stimulated bioluminescence (Widder et al. 1989). Because of this, the RMT25 is likely to be well illuminated by bioluminescent organisms during its passage through the water. However, whether this illumination produces a neutral, avoidance, or attractive effect is not presently known, but the RMT25 is nonetheless an effective net for catching large numbers of nektonic organisms.

\section{Small-scale distributions}

The distribution of the gelatinous organisms collected by the RMT25 and H-AMPS nets indicates that some species were located in narrow depth ranges. Specimens of the hippopodid siphonophore Vogtia serrata were only collected in 4 hauls, 3 of them sampled obliquely from the $400-600 \mathrm{~m}$ depth range and the fourth horizontally at $600 \mathrm{~m}$. This restricted vertical distribution appears to be a trophic interaction. Pugh (1991) described ostracods as being the main prey of hippopodid siphonophores. In the nekton/zooplankton samples taken during Cruise JR06, the bulk of the these crustaceans was observed in these layers, particularly at $600 \mathrm{~m}$.

On the other hand, only 1 ctenophore was caught at Stn 289 between 300 and $350 \mathrm{~m}$, whereas they were the predominant zooplankters in the 375-400 m depth range. This distinct vertical distribution may be associated with a discontinuity in the temperature (from 2.18 to $\left.2.28^{\circ} \mathrm{C}\right)$ and salinity $(34.25$ to $34.35 \mathrm{psu})$ at $350 \mathrm{~m}$.

\section{Wet biovolume}

Gelatinous organisms were present in most of the 22 RMT25 hauls. They constituted the predominant component ( $>50 \%$ wet biovolume) in $7(31.8 \%)$ of these hauls, which encompassed all the depth ranges sampled (Fig. 4A) but were absent from 2 rather exceptional hauls where only small volumes ( 7 and $35 \mathrm{ml}$ ) of zooplankton were collected. When biovolume was greater than 21 in a sample, it was always the result of a large component of gelatinous organisms (Fig. 4B). The most important contributor was Periphylla periphylla, some specimens of which measured more than $30 \mathrm{~cm}$ in diameter and $1 \mathrm{l}$ in wet biovolume. This species achieved a considerable biomass in 2 pelagic trawl hauls made in the upper layers at night. The first (Stn 257) collected 8 specimens with a volume of $2 \mathrm{l}$ with, in addition, an indeterminate number of broken specimens measuring ca 81 . The highest wet biovolume was collected by the pelagic trawl at Stn 367 , where 60 large specimens $(30.32 \pm 7.75 \mathrm{~cm}$ in diameter) were caught and their wet biovolume was approximately 721 .

Other species that contributed to the biovolume to a lesser extent were the scyphomedusan Atolla wyvillei, the trachymedusae Crossota brunnea and Halicreas minimum (800-1000 m) and the siphonophore Rosacea $\mathrm{sp}$. Of note are 2 specimens of the hydroidomedusa 
NON-GELATINOUS NEKTON GELATINOUS NEKTON

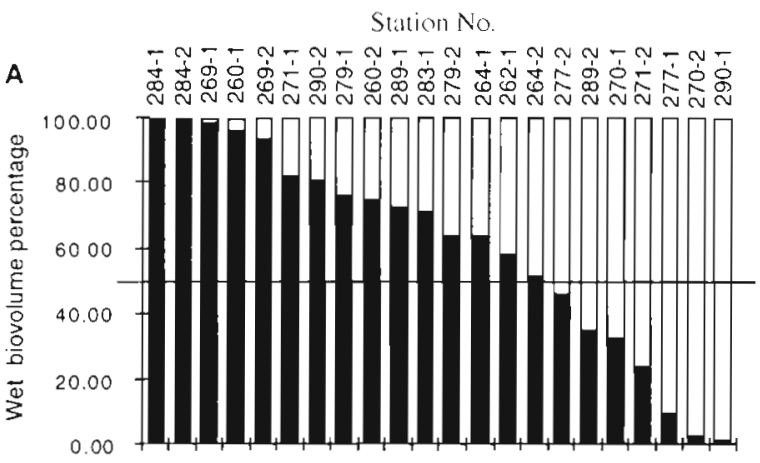

B

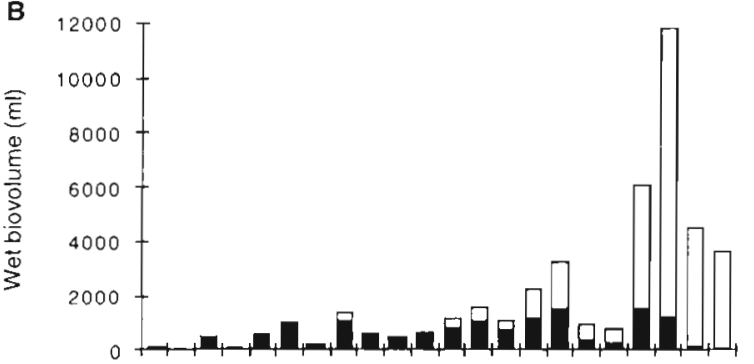

C

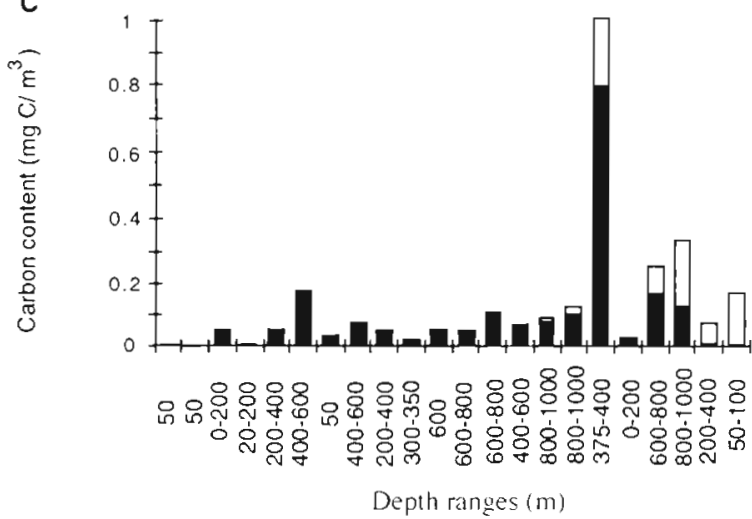

Fig. 4. (A) Wet biovolume percentage from RMT25 catches ranked in ascending order by proportion of gelatinous nekton.

(B) Wet biovolume. (C) Carbon content

Aequorea sp. (each $20 \mathrm{~cm}$ in diameter and $950 \mathrm{ml}$ in biovolume) and 1 specimen of Stygiomedusa gigantea (Browne) $(52 \mathrm{~cm}$ in diameter). The latter specimen had a wet biovolume of 41 despite the fact that the 4 thick, ribbon-like oral arms were missing. Based on observations of S. gigantea given by Larson (1986a), the oral arms should have been at least $10 \mathrm{~m}$ in length and therefore the biovolume of the intact organism would have been considerably higher

The wet biovolume contributed by the remaining gelatinous species could be considered negligible. Nevertheless, large ctenophores (up to $15 \mathrm{~cm}$ length) comprised most of the biovolume at Stn 289 (375$400 \mathrm{~m}$, Beroe sp.) and at Stns 422 and 423 (surface, Beroe cucumis Fabricius). On average, gelatinous nekton contributed $69.3 \%$ to the biovolume of the RMT25 samples, although the range was high (0 to $98.9 \%$ ). These percentages were higher than those reported by Pagès et al. (1994) and Pugh et al. (in press) in the Weddell Sea, indicating that the APFZ is a region with a higher relative contribution of gelatinous nekton, although both the larger mouth area and the larger volume of water filtered by the RMT25 may have influenced these increments.

The high water content ( 91 to $96.5 \%$; Larson 1986b, Clarke et al. 1992) strongly contributes to the wet weight of gelatinous organisms, which has been often considered as a reason to disregard the importance of these organisms in the pelagic ecosystem. However, recent studies show that excretion and respiration rates of gelatinous zooplankton are in the same range as those produced by non-gelatinous zooplankton if carbon content is used as body-mass unit (Schneider 1990, 1992).

\section{Carbon content}

In order to convert the biovolume data $\left(\mathrm{ml} 10^{4} \mathrm{~m}^{-3}\right)$ to

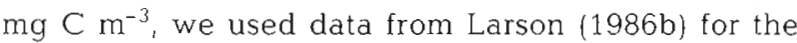
gelatinous organisms and the corrected formula in Wiebe (1988) for non-gelatinous nekton. We took Larson's mean DW\%WW (dry wt as a percentage of wet wt) and Carbon\%DW and assumed a density of 1.025 , to produce a conversion factor of 0.0003649 . These data (Fig. 4C) show that the gelatinous organisms make a comparatively large contribution to the overall biomass of the samples, averaging $30.3 \%$ of the total carbon, although the range (0 to $62.6 \%$ ) was large. Also in this event, average carbon was $5.0 \%$ higher than that estimated by Pugh et al. (in press) in the eastern Weddell Sea. Nevertheless, the 2 pelagic trawl hauls made in the upper layers that collected mainly Periphylla periphylla would have considerably increased the contribution of gelatinous nekton to the carbon content in such layers.

It is worth noting that the highest carbon content showed by non-gelatinous nekton and the second highest value for the gelatinous one were observed at Stn 289-2 (Fig. 4C) where both the shortest depth range $(375-400 \mathrm{~m})$ and the smallest volume of water $\left(11049 \mathrm{~m}^{3}\right)$ were sampled. These points indicate the ecological importance that organism aggregations at discrete depth layers may have in the flux of carbon throughout the water column.

Pelagic tunicates and coelenterates are voracious consumers that feed heavily upon phyto- and zoo- 
plankton, respectively (Purcell 1992, Mills 1995, Madin \& Deibel in press). The carbon content of their tissues is low, but the amount that passes through their guts as food is high. Much of the carbon content of a salp probably resides in the phytoplankton and microzooplankton packed into its nucleus (Kashkina 1987). Often this is poorly digested and later excreted as cohesive fastsinking fecal pellets (Caron et al. 1989). In the case of siphonophores, they commonly have 5 to 150 feeding polyps distributed along the stem, and the total tentacle length can reach several metres (Biggs 1977). However, this part of the colony is rarely considered in estimating carbon content as, due to its extreme fragility, it is usually lost during sampling by nets. For instance, the warm-water calycophoran Chelophyes appendiculata (Eschscholtz) showed a high mean carbon content $(23.4 \% \mathrm{DW})$ and nitrogen content $(6.8 \% \mathrm{DW})$ in comparison with other gelatinous zooplankton when complete specimens were used for the measurements (Gorsky et al. 1988). In the Southern Ocean, the carbon content $(10.6 \% \mathrm{DW})$ of the stem with cormidia of the common epipelagic species Diphyes antarctica Moser is similar to that of the nectophores $(11.5 \%$ DW) (Ikeda \& Bruce 1986).

\section{Biotic associations}

A few associations were observed after each haul. The large Periphylla periphylla specimen $140 \mathrm{~cm}$ in diameter) collected at Stn 290 (50-100 m depth) held in the subumbrella 3 adults ( 2 females and 1 male) of the hyperiid amphipod Cyllopus magellanicus Dana and 1 juvenile female of Themisto gaudichaudii Guérin. Surprisingly, no other gelatinous specimens held hyperiid amphipods. Our observations agree with Weigmann-Haass (1983), who suggested that $C$ magellanicus could be a parasite of gelatinous organisms because this species had some morphological adaptations similar to those of other hyperiids which are known to be parasitic. On the other hand, the $4460 \mathrm{ml}$ wet biovolume measured at Stn 270 (200-400 m depth) was mostly due to 2 large specimens of $P$. periphylla (30 and $35 \mathrm{~cm}$ in diameter) The only conspicuous organism caught in the same haul was a single specimen of the rare centrolophid Icichthys australis Haedrich which measured $90 \mathrm{~mm}$ in total length. The family Centrolophidae comprises several genera and species of fishes associated with scyphozoans (Thiel 1970, 1978). Haedrich (1966) remarked, in the original description of this species, that $I$. australis might not be associated with jellyfish because no medusae were reported in the haul that caught the holotype. However, $I$. australis and medusae co-occurred in other collections at South Georgia (White \& North 1980, M. G.
White pers. obs.) and the co-occurrence in this study suggests that the general association between centrolophids and medusae is also true for the Southern Ocean species.

\section{Predation}

A few observations regarding some predators of gelatinous nekton were made in the vicinity of South Georgia. For instance, a group of almost 20 albatrosses were observed foraging on a large reddish medusae (R. R. Veit pers. comm.) which was probably a specimen belonging to one of the large medusan genera Desmonema or Diplulmaris. Elsewhere, at the South Orkney Islands, cape pigeons Daption capense Linnaeus have been observed feeding on the amphipods associated with the large scyphomedusa Desmonema gaudichaudii (Lesson) (M. G. White pers. obs.). Likewise, a great number of specimens of Notothenia rossii collected by the MV 'Cordella' on the South Georgia shelf at the same time as the JR06 cruise had numerous ctenophores in their stomachs (C. Goss pers. comm.). Ctenophores were the overwhelmingly predominant zooplankters in some F-net hauls made in the area and they have been reported as a common prey item for nototheniids (Pakhomov 1993). Nonetheless, we presume that mesopelagic medusae are food sources for a wide variety of Antarctic mesopelagic crustaceans such as has been reported in the North Atlantic, where amphipods, shrimps and pycnogonids have been observed in situ feeding on Periphylla and Atolla (Harbison et al. 1977, Child \& Harbison 1986, Moore et al. 1993)

Additional observations recorded near South Georgia indicate that gelatinous nekton may also be important in neritic waters. Some ctenophores and the large scyphomedusa Desmonema occur in high densities and biomass around this island (Ward 1989) where the former are often very abundant in the fjords (M. G. White pers. obs.). Ctenophores are known to be major zooplankton predators in the northern hemisphere (Swanberg \& Båmstedt 1991) and observations that they may occur in great number in the Southern Ocean implies that sometimes they may also be important in influencing the food web in Antarctic waters. Likewise diving observations on Desmonema made at Signy Island, South Orkney Islands, showed that this medusa is common in neritic waters and is a benthopelagic predator (White \& Bone 1972) but there are few other reports about its biology. Around South Georgia, gelatinous nekton appear to be common prey for seabirds and fish when krill populations are depleted, as happened during summer 1994 (Brierley \& Watkins 1995). 


\section{CONCLUSIONS}

The above results support the premise that gelatinous organisms are a major and, at times, the main component of the oceanic macroplankton/nekton community in the Southern Ocean. Salps are not the only dominant gelatinous group and this study has shown that gelatinous carnivores, particularly medusae, can be a predominant component of the nekton community in terms of biovolume and carbon content. Species diversity increases with depth, reaching the highest values in mesopelagic layers where biotic associations with fish, amphipods and probably other crustaceans occur. However, little is known about important aspects of their biology, particularly reproduction, feeding and growth. Knowledge about abundance and spatio-temporal distribution is restricted to some areas of the Atlantic sector in summer. More information on these matters over the year in other parts of the Southern Ocean would greatly contribute to our understanding and allow us to evaluate the role played by these organisms in the Antarctic pelagic ecosystem.

Acknowledgements. This work was supported by a Spanish Ministry of Education and Science (EX92 46331867) grant to F.P. This is Alfred-Wegener-Institut contribution 931 We thank the officers and crew of the RRS 'James Clark Ross' for their support and professionalism, and also the participants of Cruise JR06 for unselfish help and advice.

\section{LITERATURE CITED}

Biggs DC (1977) Field studies of fishing, feeding and digestion in siphonophores. Mar Behav Physiol 4:261-274

Brierley AS, Watkins JL (1995) An acoustic estimation of krill densities to the north of South Georgia in January 1994. Document WG-EMM-95/74, CCAMLR, Hobart

British Antarctic Survey (1995) Structure and dynamics of the Southern Ocean ecosystem. In: Annual report 1993-1994 British Antarctic Survey, p 75-90

Caron DA, Madin LP, Cole JJ (1989) Composition and degradation of salp fecal pellets: implications for vertical flux in oceanic environments. J Mar Res 47:829-850

Child C. Harbison GR (1986) A parasitic assoclation between a pycnogonid and a scyphomedusa in midwater. J Mar Biol Ass UK 66:113-117

Clarke A, Holmes LJ, Gore DJ (1992) Proximate and elemental composition of gelatinous zooplankton from the Southern Ocean. J Exp Mar Biol Ecol 155:55-68

Everson I, Miller DGM (1994) Krill mesoscale distribution and abundance: results and implications of research during the BIOMASS programme. In: El-Sayed SZ (ed) Southern Ocean ecology. The BIOMASS perspective. Cambridge University Press, Cambridge, p 129-143

Galt CP (1989) Bioluminescence of gelatinous zooplankton. Oceanis 15:51-59

Gorsky G, Dallot S, Sardou J, Fenaux R, Carré C, Palazzoli I (1988) C and N composition of some northwestern Mediterranean zooplankton and micronekton species. J Exp Mar Biol Ecol 124:133-144
Haedrich RL (1966) The stromateoid fish genus lcichthys. notes and a new species. Vidensk Medd Dan Naturhist Foren 129:199-213

Harbison RG, Biggs DC, Madin LP (1977) The associations of Amphipoda Hiperiidea with gelatinous zooplankton - II. Associations with Cnidaria, Ctenophora and Radiolaria. Deep Sea Res 24:465-488

Herring PJ (1990) Bioluminescent responses of the deep-sea scyphozoan Atolla wyvillel. Mar Biol 106:413-417

Heywood RB, Everson 1. Priddle J (1985) The absence of krill from the South Georgia zone, winter 1983. Deep Sea Res 32(3A):369-378

Huntley ME, Sykes PF, Marin V (1989) Biometry and trophodynamics of Salpa thompsoni Foxton (Tunicata: Thaliacea) ncar the Antarctic Peninsula is dustral summer, 1983-84. Polar Biol 10:59-70

Ikeda T, Bruce B (1986) Metabolic activity and elemental composition and other zooplankton from Prydz Bay, Antarctica, during early summer (November-December). Mar Biol 92:545-555

Janssen J, Gibbs RH Jr, Pugh PR (1989) Association of Caristius sp. (Pisces: Caristiidae) with a siphonophore, Bathyphysd conifera. Copeia 1:198-201

Kashkina AA (1987) Feeding of fishes on salps (Tunicata, Thaliacea). J Ich thyol 26:57-64

Kock KH, Shimadzu Y (1994) Trophic relationships and trends in population size and reproductive parameters in Antarctic high-level predators. In: El-Sayed SZ (ed) Southern Ocean ecology. The BIOMASS perspective. Cambridge Unıversity Press, Cambridge, p 287-312

Larson RJ (1986a) Pelagic Scyphomedusae (Scyphozoa: Coronatae and Semaeostomae) of the Southern Ocean. Biology of the Antarctic Seas XVI. Ant Res Ser 41:59-165

Larson RJ (1986b) Water content, organic content, and carbon and nitrogen composition of medusae from the northeast Pacific. J Exp Mar Biol Ecol 99:107-120

Madin LP, Deibel D (in press) Feeding and energetics of thaliaceans. In: Bone $Q$ (ed) The biology of pelagic tunicates. Oxford University Press, Oxford

Mills CE (1995) Medusae, siphonophores and ctenophores as planktivorous predators in changing global ecosystems. ICES J Mar Sci 52:575-581

Moore PG, Rainbow PS, Larson RJ (1993) The mesopelagic shrimp Notostomus robustus Smith (Decapoda: Oplophoridae) observed in situ feeding on themedusan Atolla wyvillei Haeckel in the Northwest Atlantic, with notes on gut contents and mouthpart morphology. J Crust Biol 13: 690-696

Pagès F, Kurbjeweit F (1994) Vertical distribution and abundance of mesoplanktonic medusae and siphonophores from the Weddell Sea. Antarctica. Polar Biol 14:243-251

Pagès F, Pugh PR, Gili JM (1994) Macro- and megaplanktonic cnidarians collected in the eastern part of the Weddell Gyre during summer 1979. J Mar Biol Ass UK 74:873-894

Pakhomov YeA (1993) Feeding habits and estimate of ration of Gray Notothenla, Notothenia squamifrons squamifrons, on the $\mathrm{Ob}$ and Lena tablemounts (Indian sector of Antarctica). J Ichthyol 33:57-71

Piatkowski U, Rodhouse PG, White MG, Bone DG, Simon C (1994) Nekton community of the Scotia Sea as sampled by the RMT25 during austral summer. Mar Ecol Prog Ser 112: $1.3-28$

Pugh PR (1991) Co-occurrence of hippopodiid siphonophores and their potential prey. Hydrobiologia 216/217:327-334

Pugh PR, Pagès F, Boorman B (in press) The vertical distribution of cnidarians in the eastern part of the Weddell Sea, Antarctica. J Mar Biol Ass UK 
Purcell JE (1992) Effects of predation by the scyphomedusan Chrysaora quinquecirrtia on zooplankton populations in Chesapeake Bay, USA. Mar Ecol Prog Ser 87:65-76

Reinke M (1987) Zur Nahrungs- und Bewegungsphysiologie von Salpa thompsoni und Salpa fusiformis. Ber Polarforsch 36:1-89

Rodhouse PG, Piatkowski U, Murphy EJ, White MG, Bone DG (1994) Utility and limits of biomass spectra: nekton community sampled with the RMT25 in the Scotia Sea during austral summer. Mar Ecol Prog Ser 112:29-39

Rodhouse PG, Prince PA, Trathan PN, Hatfield EMC, Watkins JL, Bone DG, Murphy EJ, White MG (1996) Cephalopods and mesoscale oceanography at the Antarctic Polar Front: satellite tracked predators locate pelagic trophic interactions. Mar Ecol Prog Ser 136:37-50

Rodhouse PG, White MG (1995) Cephalopods occupy the ecological niche of epipelagic fish in the Antarctic Polar Frontal Zone. Biol Bull 189:77-80

Schneider G (1990) A comparison of carbon based ammonia excretion rates between gelatinous and non-gelatinous zooplankton: implications and consequences. Mar Biol 106:219-225

Schneider G (1992) A comparison of carbon-specific respiratıon rates in gelatinous and non gelatinous zooplankton: a search for general rules in zooplankton metabolism. Helgoländer Meeresunters 46:377-388

Shimomura O, Johnson FH, Saiga Y (1962) Extraction, purification and properties of aequorin, a bioluminescent protein from the luminous hydromedusan, Aequorea. J Cell Comp Physiol 59:223-240

Siegel V, Loeb V (1995) Recruitment of Antarctic krill (Euphausia superba) and possible causes for its variability. Mar Ecol Prog Ser 123:45-56

This article was submitted to the editor
Swanberg N, Bămstedt U (1991) The role of prey stratification in the predation pressure by the cydippid ctenophore Mertensia ovum in the Barents Sea. Hydrobiologia 216/217:343-349

Thiel ME (1970) Das Zusammenleben von Jung- und Kleinfischen mit Rhizostomeen. Ber Dtsch Wiss Komm Meeresforsch 21:444-473

Thiel ME (1978) Das Zusammenleben von Jung- und Kleinfischen mit Semaeostomen (Scyphomedusae). Mitt Hamb Zool Mus Inst 75:9-47

Ward P (1989) The distribution of zooplankton in an Antarctic fjord at South Georgia during summer and winter. Antarct Sci 1:141-150

Weigmann-Haass R (1983) Zur Taxonomie und Verbreitung der Gattung Cyllopus Dana 1853 (Amphipoda: Hyperiidea) im antarktischen Teil des Atlantik. 'Meteor' Forsch.Ergebn Reihe D 36:1-11

White MG, Bone DG (1972) The interrelationship of Hyperia galba (Crustacea, Amphipoda) and Desmonema gaudichaudi (Scyphomedusae, Semaeostomae) from the Antarctic. Br Antarct Surv Bull 27:39-49

White MG, North AW (1980) Pseudoicichthys australis (Pisces, Centrolophidae): an addition to the marine fauna of South Georgia and confirmation of Antarctic distribution. Br Antarct Surv Bull 50:113-115

Widder EA, Bernstein SA, Bracher D, Case JF, Reisenbichler KR, Torres JJ, Robison BH (1989) Bioluminescence in the Monterey Submarine Canyon: image analysis of video recordings from a midwater submersible. Mar Biol 100: $541-551$

Wiebe PH (1988) Functional regression equations for zooplankton displacement volume, wet weight, dry weight, and carbon: a correction. Fish Bull US 86:833-835

Manuscript first received: September 6, 1995

Revised version accepted: June 18, 1996 